\title{
Candida Rugosa Lipase Immobilized on Hydrophobic Support Accurel MP 1000 in the Synthesis of Emollient Esters
}

Luiz Henrique Sales de Menezes

Universidade Estadual de Santa Cruz

Eliezer Luz do Espírito Santo

Universidade Estadual de Santa Cruz

Marta Maria Oliveira dos Santos

Universidade Federal de Alagoas

lasnaia Maria de Carvalho Tavares

Universidade Estadual do Sudoeste da Bahia - Campus Itapetinga

Adriano Aguiar Mendes

Universidade Federal de Alfenas

Marcelo Franco

Universidade Estadual de Santa Cruz

Julieta Rangel de Oliveira ( $\boldsymbol{\nabla}$ jroliveira@uesc.br)

Universidade Estadual de Santa Cruz https://orcid.org/0000-0001-8571-7294

\section{Research Article}

Keywords: Accurel MP 1000, Biocatalysis, Esterification, Immobilization

Posted Date: May 26th, 2021

DOl: https://doi.org/10.21203/rs.3.rs-509734/v1

License: (a) This work is licensed under a Creative Commons Attribution 4.0 International License. Read Full License

Version of Record: A version of this preprint was published at Biotechnology Letters on November 5th, 2021. See the published version at https://doi.org/10.1007/s10529-021-03196-w. 
8 10

\section{Candida rugosa lipase immobilized on hydrophobic support Accurel MP 1000 in the synthesis of}

\section{emollient esters}

Luiz Henrique Sales de Menezes ${ }^{1}$, Eliezer Luz do Espírito Santo ${ }^{1}$, Marta Maria Oliveira dos Santos ${ }^{2}$, Iasnaia Maria de Carvalho Tavares ${ }^{3}$, Adriano Aguiar Mendes ${ }^{4}$, Marcelo Franco ${ }^{1}$, Julieta Rangel de Oliveira $^{1 *}$

${ }^{1}$ Department of Exact and Technological Sciences, State University of Santa Cruz, 45654-370, Ilhéus/BA, Brazil.

${ }^{2}$ Institute of Chemistry and Biotechnology, Federal University of Alagoas, 57072-900, Maceió/AL, Brazil ${ }^{3}$ Department of Exact and Natural Sciences, State University of Southwest Bahia, 45700-000, Itapetinga/BA, Brazil.

${ }^{4}$ Institute of Chemistry, Federal University of Alfenas, 37130-001, Alfenas/MG, Brazil.

Corresponding author*

Departament of Exact Sciences and Technology, State University of Santa Cruz (UESC), Ilhéus, Brazil Email: jroliveira@uesc.br

Telephone: (73) 36805355 
In the present work, Candida rugosa lipase (CRL) was immobilized by physical adsorption in organic medium on Accurel MP 1000 (AMP) with a protein load of $6.5 \mathrm{mg} \mathrm{g}^{-1}$ (mg protein/g support). CRL-AMP was applied with 5 and $10 \%$ of catalyst/volume of medium $\left(\mathrm{m} \mathrm{v}^{-1}\right)$ in esterification reactions of stearic acid with lauryl and cetyl alcohols producing the wax esters such as dodecanoyl octadecanoate $\mathbf{1}$ and hexadecanoyl octadecanoate $\mathbf{2}$ in a heptane medium. Six reaction cycles were studied to evaluate the stability and recyclability of the prepared biocatalyst. The specific activity $\left(\mathrm{A}_{\mathrm{sp}}\right)$ for CRL-AMP was $200 \pm$ $20 \mathrm{U} \mathrm{mg}^{-1}$. Its catalytic activity was $1300 \pm 100 \mathrm{U} \mathrm{g}^{-1}$. CRL-AMP was used in the synthesis of esters in heptane medium with a 1:1 acid:alcohol molar ratio at $45^{\circ} \mathrm{C}$ and $200 \mathrm{rpm}$. In synthesis $\mathbf{1}$, conversion was $62.5 \pm 3.9 \%$ in $30 \mathrm{~min}$ at $10 \% \mathrm{~m} \mathrm{v}^{-1}$ and $56.9 \pm 2.8 \%$ in $54 \mathrm{~min}$ at $5 \% \mathrm{~m} \mathrm{v}^{-1}$, while in synthesis 2 , conversion was $79.0 \pm 3.9 \%$ in $24 \mathrm{~min}$ at $10 \% \mathrm{~m} \mathrm{v}^{-1}$, and $46.0 \pm 2.4 \%$ in $54 \mathrm{~min}$ at $5 \% \mathrm{~m} \mathrm{v}^{-1}$. Reuse tests after 6 consecutive cycles of reaction showed that the biocatalyst retained approximately $50 \%$ of its original activity for both reaction systems. CRL-AMP showed a high potential in the production of wax esters, since it started from low enzymatic load and high specific activities and conversions were obtained, in addition to allowing an increase in stability and recyclability of the prepared biocatalyst.

Keywords: Accurel MP 1000; Biocatalysis; Esterification; Immobilization. 


\section{Introduction}

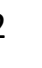
weight, formed by long chain alcohols and carboxylic acids (Serrano-Arnaldos et al., 2016). These esters are neither toxic nor greasy (Khan et al., 2015), they are classified as fine chemical products (Rani et al., 2015) and are commonly used in the cosmetic, pharmaceutical and lubricant industries (Lima et al., 2018; Miguez et al., 2018). Naturally, wax esters can be obtained from animal and vegetable sources and have distinct compositions (Ungcharoenwiwat et al., 2015). However, natural wax esters are not readily available, which increases their commercial value. Thus, synthetic esters are considered promising substitutes to natural esters (Kuo et al., 2012).

Wax ester synthesis reactions are usually catalyzed by toxic and corrosive chemical compounds such as hydrofluoric acid and sulfuric acid (Esfandmaz et al., 2018). The disadvantages of processes catalyzed by strong acids are high reaction temperatures, difficult separation of reaction media, low yields and environmental concerns (Cui et al., 2020). However, the enzymatic route has proved attractive for the production of these esters because it is a process with low energy consumption, high productivity, and good stability compared to organic solvents (Bandikari et al., 2018), in addition to having broad substrate specificity and exhibiting high enantioselectivity (Benamia et al., 2016).

Among the enzymes used in the synthesis of esters with emollient properties, lipases (triacylglycerol acyl-hydrolases, EC 3.1.1.3) stand out (Novaes et al., 2018; Cea et al., 2019) for their application in the hydrolysis of triacylglycerols into glycerol and free fatty acids in aqueous media. In organic medium, they catalyze transesterification, interesterification and esterification reactions for producing valuable esters such as wax esters (De Menezes et al., 2021). Lipases present two different configurations, closed configuration, where contact between the active site and the reaction medium is blocked, and open configuration, where the active site is exposed to the reaction medium (Manoel et al., 2015). In order to prolong the applicability of lipases in syntheses of emollient esters and other industrial processes, the study of new techniques that allow its reuse is necessary, among these techniques, immobilization stands out (Cea et al., 2019).

Enzymatic immobilization is the confinement of protein on an insoluble solid support in aqueous and in organic solvents media and is applied to improve catalytic efficiency and allow its reuse (Manoel et al., 2015; Hadadi et al., 2019). Physical adsorption is a technique of enzymatic immobilization that 
occurs through non-covalent bonds such as hydrophobic interactions, Van der Waals forces, hydrogen bonds and ionic bonds (Bolina et al., 2018). In this type of immobilization, lipases are adsorbed on relatively porous supports and this process involves the open form of lipases, which makes it adequate (Francolini et al., 2020).

Accurel MP 1000 (AMP) is a hydrophobic and macroporous polypropylene polymer (Cesarini et al., 2014) widely used as a support in the immobilization of lipases (Baron et al., 2011; Scherer et al., 2011; Cunha et al., 2013; Alnoch et al., 2015; Madalozzo et al., 2015; Manoel et al., 2015). Lipases immobilized on AMP are used for several purposes, such as catalysis in synthesis of biodiesel esters (Madalozzo et al., 2015; De Menezes et al., 2021), pharmacological derivatives, such as myo-inositol, a supplement that helps in hormonal disorders and fertility (Manoel et al., 2016), and catalysis of biolubricating esters from vegetable oil by-products (Fernandes et al., 2020).

Thus, this work aimed to immobilize the Candida rugosa lipase (CRL) on Accurel MP 1000 (AMP) by adsorption in organic medium and apply it in the synthesis of stearic acid with lauryl and cetyl alcohol to obtain esters with emollient properties. CRL was selected for having high hydrolytic potential, besides its efficiency in synthesis under limited water conditions (Cavalcanti et al., 2018). Stearic acid was used as a donor because it is one of the main fatty acids present in beef tallow (Aransiola et al., 2014), a low-cost raw material that is easy to obtain in Brazil, which may lead to new studies aiming at the use of bovine tallow as a substrate for the enzymatic synthesis of wax esters.

\section{Materials and Methods}

1

Candida rugosa lipase, an enzymatic powder preparation with protein concentration of $27.42 \pm$ $2.70 \mathrm{mg} \mathrm{g}^{-1}$, hydrolytic activity $37591.20 \pm 75.18 \mathrm{U} \mathrm{g}^{-1}$ and specific activity $1370.90 \pm 1.40 \mathrm{U} \mathrm{mg}^{-1}$, was acquired from Sigma-Aldrich Co. (St. Louis, MO, USA) and it was used without prior treatment. Lauryl and cetyl alcohols were also acquired from Sigma Aldrich Co. Accurel ${ }^{\circledR}$ MP 1000 beads which is a polypropylene carrier, with particle diameter $<1.5 \mathrm{~mm}$ and mean pore diameter of $25 \mathrm{~nm}$ (Sabbani et al., 2006), was obtained from 3M (Germany). Ethyl alcohol, acetone, hexane, heptane, stearic acid and acacia gum were obtained from Synth ${ }^{\circledR}$ (São Paulo, SP, Brazil). Olive oil (Carbonell, Córdoba, Spain) was purchased at the local trade market (Itabuna, Bahia, Brazil). All other reactants and organic solvents were of analytical grade supplied by Synth ${ }^{\circledR}$. 


\subsubsection{Scanning electron microscopy (SEM)}

124

126

127

128

129

130

131

132

134

135

136

137

138

139

142

143

144

145

146

The morphology of the Accurel MP 1000 support was investigated by fixing the samples on a "Stub" holder and then metallized, about 20 to $30 \mathrm{~nm}$ thick by a sputtering evaporation system using the Sputter Coater, BAL-TEC SCD050 (Fig. 1). In Fig. 1a, with a $20 \mu \mathrm{m}$ zoom, the pores of the support are shown, while in Fig. 1b, with a $100 \mu \mathrm{m}$ zoom, besides the pores, its conformation is shown.

\subsubsection{Immobilization of Candida rugosa lipase}

1

32

Accurel MP $1000(1 \mathrm{~g})$ was immersed in hexane $(15 \mathrm{~mL})$ at a ratio of $1: 10(\mathrm{~m} / \mathrm{v})$ in a becker $(100 \mathrm{~mL})$ and kept at $-6^{\circ} \mathrm{C}$ for $4 \mathrm{~h}$ in a vertical freezer. Then, $237 \mathrm{mg}$ of commercial CRL powder extract (that corresponds to an initial protein loading of $6.5 \mathrm{mg} \mathrm{g}^{-1}$ ) were added to this suspension. The resulting suspension consisting of CRL powder extract, support and solvent was kept at $-6{ }^{\circ} \mathrm{C}$ overnight in a vertical freezer to obtain the immobilized lipase. After, the biocatalyst prepared (CRL-AMP) was recovered via filtration in a Buchner funnel under vacuum and repeatedly washed with hexane to remove unbounded enzyme molecules. The immobilized lipase was then stored under refrigeration at $4{ }^{\circ} \mathrm{C}$ in a BOD incubator (TE-371, Tecnal, Piracicaba, Brazil). The immobilized protein concentration (IP $-\mathrm{mg} \mathrm{g}^{-1}$ ) was determined according to method of the Bradford et al. (1976), using bovine serum albumin (BSA) as standard (Ferreira et al., 2017), as shown in Eq. (1).

$$
I P=\frac{V_{e n z} x\left(C_{0}-C_{e}\right)}{m}
$$

where $I P$ is the immobilized lipase concentration $\left(\mathrm{mg} \mathrm{g}^{-1}\right) ; V_{e n z}$ is the volume of solution $(\mathrm{mL}) ; C_{0}$ and $C_{e}$ are respectively the initial and residual (at equilibrium) protein concentration in the immobilization supernatant $(\mathrm{mg} / \mathrm{mL})$; and $m$ is the mass of support $(\mathrm{g})$. 

concentration at equilibrium (IP $-\mathrm{mg} \mathrm{g}^{-1}$ ) and initial protein concentration used to prepare the heterogeneous biocatalyst $\left(6.5 \mathrm{mg} \mathrm{g}^{-1}\right)$.

150

\subsubsection{Determination of hydrolytic activity}

152

The hydrolytic activity (HA) of crude free CRL and immobilized lipase (CRL-AMP) was

154

155

156

157

158

159

160

161

162

163

164

determined on the hydrolysis of olive oil emulsion (Carvalho et al., 2017; Dos Santos et al., 2020). The emulsion was prepared by mixing $2.5 \mathrm{~g}$ of olive oil with $2.5 \mathrm{~g}$ of Arabic Gum solution at $7 \% \mathrm{~m} / \mathrm{v}$ and 5 $\mathrm{mL}$ of $100 \mathrm{mmol} \mathrm{L} \mathrm{m}^{-1}$ buffer sodium phosphate $\mathrm{pH}$ 7.0. This mixture was placed in a $125 \mathrm{~mL}$ conical flask and incubated in an incubator with orbital agitation (Tecnal, Piracicaba, São Paulo, Brazil) at 200 rpm and $37^{\circ} \mathrm{C}$ and added $0.1 \mathrm{~g}$ of immobilized lipase. Following this, $10 \mathrm{~mL}$ of ethanol solution at $95 \% \mathrm{~m} / \mathrm{m}$ was added to the reaction mixture and titrated with a $0.0313 \mathrm{M} \mathrm{NaOH}$ solution using phenolphthalein as indicator. Hydrolytic activity was determined as shown in Eq. (2). One international unit (U) of activity was defined as being the mass of enzyme required to release $1 \mu \mathrm{mol}$ of free fatty acid per minute of reaction. These assays were performed with three replications.

$$
H A\left(U g^{-1}\right)=\frac{\left(V_{s}-V_{c}\right) \times M \times 10^{3}}{t \times m}
$$

where $H A$ is the hydrolytic activity of the immobilized lipase $\left(\mathrm{U} \mathrm{g}^{-1}\right), V_{S}$ is the volume of $\mathrm{NaOH}$ solution used to titrate the sample $(\mathrm{mL}), V_{C}$ is the volume of $\mathrm{NaOH}$ solution used to titrate control sample $(\mathrm{mL}), M$ is the concentration of $\mathrm{NaOH}$ solution $\left(\mathrm{mol} \mathrm{L}^{-1}\right), t$ is the reaction time (min) and $m$ is the mass of immobilized lipase (g).

Specific Activity $\left(\mathrm{A}_{\mathrm{sp}}-\mathrm{U} \mathrm{mg}^{-1}\right)$ was calculated according to Eq. (3) (Teodoro et al., 2019):

$$
\mathrm{A}_{\mathrm{sp}}\left(\mathrm{U} \mathrm{mg}^{-1}\right)=\frac{H A}{I P}
$$

where $H A$ is the hydrolytic activity of the prepared biocatalysts $\left(\mathrm{U} \mathrm{g}^{-1}\right)$ and $I P$ is the immobilized protein concentration at equilibrium $\left(\mathrm{mg} \mathrm{g}^{-1}\right)$. 


\subsubsection{Esterification reaction}

177

The esterification reactions between stearic acid and alcohols (lauryl and cetyl) were performed in closed Duran flasks $(25 \mathrm{~mL})$, containing $6 \mathrm{~mL}$ of reaction medium and $500 \mathrm{mmol} \mathrm{L}^{-1}$ of each reagent (acid:alcohol, 1:1) in heptane medium. The reaction mixtures were immersed in an orbital shaker (Tecnal, Piracicaba, São Paulo, Brazil) at $200 \mathrm{rpm}$ and $45^{\circ} \mathrm{C}$ by $15 \mathrm{~min}$ to dissolve starting materials (alcohols and fatty acids) before adding the immobilized lipase (CRL-AMP). The schematic synthesis reactions of the two esters are shown in Fig. 2. In each flask, the CRL-AMP was added in different concentrations (5 and $10 \%$ of catalyst/volume of medium) $\left(\mathrm{m} \mathrm{v}^{-1}\right)$. Periodically, aliquots $(100 \mu \mathrm{L})$ from the reaction mixture were removed, diluted in $10 \mathrm{~mL}$ of an ethanol/acetone 1:1 (v/v) mixture and titrated with $\mathrm{NaOH}$ solution (0.0313 M) using phenolphthalein as indicated (Alves et al., 2016; Lage et al., 2016). The conversion (\%), based on acid consumption in the reaction, was calculated according to Eq. (4). Control assays were conducted by adding AMP beads to the reaction mixtures and no acid consumption was detected under such experimental conditions.

190

$$
\text { Conversion }(\%)=\left(\frac{A_{\text {in }}-A_{\text {fin }}}{A_{\text {in }}}\right) \times 100
$$

191

192 193

Where $\mathrm{A}_{\text {in }}$ and $\mathrm{A}_{\text {fin }}$ are the initial and final concentrations of fatty acid in the reaction medium (mmol $\left.\mathrm{L}^{-1}\right)$.

\subsubsection{Reuse of CRL-AMP}

Two different reactional media were employed, both consisting of $6 \mathrm{~mL}$ and in the presence of heptane. The first containing lauryl alcohol and stearic acid and the second containing cetyl alcohol and stearic acid. The media were placed in Duran flasks $(25 \mathrm{~mL})$ at $45{ }^{\circ} \mathrm{C}$ and $200 \mathrm{rpm}$ in an incubator with orbital agitation (Tecnal, Piracicaba, São Paulo, Brazil). The reaction was initiated by the addition of CRL-AMP in concentrations 5 and $10 \%$ of catalyst/volume of medium $\left(\mathrm{m} \mathrm{v}^{-1}\right)$ and the duration of each reaction is described in Table 1. The conversion was determined by titulometric method (Silva et al., 
2017). After a reaction cycle, the CRL-AMP was filtered and washed with excess refrigerated hexane (50 $\mathrm{mL}$ ), to remove molecules from reagents or products retained in the microenvironment of the catalyst. Finally, the CRL-AMP was stored at $4^{\circ} \mathrm{C}$ in a BOD incubator (TE-371, Tecnal, Piracicaba, Brazil) for 24 hours. This process was performed 6 times, totaling 6 reaction cycles.

\section{Results and Discussion}

\subsection{Obtaining the CRL-AMP}

The catalytic properties of the prepared CRL-AMP were determined after quantification of the HA (determining property in catalytic efficiency) in free and immobilized lipase to determine the catalytic activity of the immobilized enzyme, whose observed HA values were $8917.57 \pm 249.29 \mathrm{U} \mathrm{g}^{-1}$ and $1300 \pm 100 \mathrm{U} \mathrm{g}^{-1}$, respectively. The immobilization yield was $100 \%$, since the immobilization procedure was performed in organic solvent medium without free water due to the high hydrophobicity of AMP (Cesarini et al., 2014). This reduces the interaction of the aqueous phase containing the enzyme with the support, thus, immobilization in organic medium was chosen, a method that has been used by several other researchers (Bento et al., 2017; Silva et al., 2018; Da Silva et al., 2020). Complete immobilization was confirmed by method of the Bradford et al. (1976).

The specific activity $\left(A_{s p}\right)$ of the free and immobilized enzyme was determined, obtaining $324 \pm$ 32 and $200 \pm 20 \mathrm{U} \mathrm{mg}^{-1}$, respectively. After being immobilized, the lipase reduced its $\mathrm{A}_{\mathrm{sp}}(324 \pm 32 \mathrm{U}$ $\mathrm{mg}^{-1}$ ) to $200 \pm 20 \mathrm{U} \mathrm{mg}^{-1}$. This reduction indicates that the lipase molecules are not accessible to the drops of olive oil and the immobilization of CRL occurred in the internal part of the AMP, because CRL is a globular protein with molecular size of $50 \AA \times 42 \AA \times 33 \AA$ (Gao et al., 2010) and molecular diameter of near $0.5 \mathrm{~nm}$ (much smaller than the average diameter of the AMP pores, $25 \mathrm{~nm}$ (Sabbani et al., 2006)). The molecular diameter of CRL was determined by equations 5 and 6 :

$$
R_{e n z}=\sqrt[3]{\frac{3 V_{e n z}}{4 \pi}}
$$

$$
D_{\text {enz }}=2 R_{\text {enz }}
$$



diameter.

\subsection{Application of CRL-AMP in synthesis of emollient esters}

233

CRL-AMP was applied in the synthesis of dodecanoyl octadecanoate $\mathbf{1}$ and hexadecanoyl octadecanoate 2 via direct esterification reactions of octadecanoic acid (stearic acid) and alcohols in heptane medium. In order to obtain larger conversions, the influence of time on the esterification reaction was evaluated by removing aliquots at fixed-time intervals $(6 \mathrm{~min})$ in the respective concentrations of CRL-AMP (Fig. 3). The free enzyme (powder extract) contains in its composition stabilizing agents such as proteins, sugars and salts, and when using it as a catalyst in the esterification reaction, the water produced in the reaction is adsorbed in its microenvironment causing strong aggregation, thus decreasing its catalytic activity. On the other hand, by using the immobilized enzyme on hydrophobic support, this adsorption in water is lower, thus, the dispersion of the catalyst in the medium improves significantly and favors contact of the enzyme with the raw material, besides increasing the rate of the reaction (Lage et al., 2016)

In synthesis 1 (Fig. 2) (Table 1), using CRL-AMP 10\% in mass of biocatalyst by volume of medium $\left(\mathrm{m} \mathrm{v}^{-1}\right)$, conversion $62.5 \pm 3.9 \%$ (Fig. 3) was obtained in $30 \mathrm{~min}$ of reaction, after this time the conversion rate remained stable. The conversion was adequate, since the protein load of the CRL-AMP used was only $6.5 \mathrm{mg} \mathrm{g}^{-1}$. Meanwhile, CRL-AMP $5 \% \mathrm{~m} \mathrm{v}^{-1}$ obtained $56.9 \pm 2.8 \%$ (Fig. 3) in 54 min, and in the first $30 \mathrm{~min}$ the reaction produced less than $20 \%$ of ester and after 54 min it remained constant. In synthesis 2 (Fig. 2) (Table 1), conversion was $46.0 \pm 2.4 \%$ in $54 \mathrm{~min}$ and $79.0 \pm 3.9 \%$ (Fig. 3) in $24 \mathrm{~min}$ were obtained with CRL-AMP 5 and $10 \% \mathrm{~m} \mathrm{v}^{-1}$, respectively, and after the indicated times, the conversions remained constant, indicating that the reaction reached chemical equilibrium. When the enzymatic concentration of catalyst was doubled ( 5 to $\left.10 \% \mathrm{~m} \mathrm{v}^{-1}\right)$, there was an increase in the conversion and reduction in time, thus, the synthesis reaction was controlled by kinetics (not mass tranfer) (Yadav et al., 2012). 


$$
\mathrm{P}\left(\mu \mathrm{mol} \min ^{-1} m g_{\text {protein }^{-1}}\right)=\frac{\mathrm{N}_{\mathrm{a}} \times 10^{3}}{\mathrm{t}_{\mathrm{eq}} \mathrm{Xm}}
$$

Where $\mathrm{N}_{\mathrm{a}}$ is the concentration of consumed carboxylic acid (mmol); $t$ is the reaction time in equilibrium; and $\mathrm{m}$ is the concentration of immobilized protein.

After the calculations, the productivities 2700 and $2670 \mu \mathrm{mol} \mathrm{min}^{-1} \mathrm{mg}_{\text {protein }}{ }^{-1}$ were found for 5 and $10 \% \mathrm{~m} \mathrm{v}^{-1}$, respectively (synthesis $\mathbf{1}$ ) and 2180 and $4220 \mu \mathrm{mol} \mathrm{min}^{-1} \mathrm{mg}_{\text {protein }}{ }^{-1}$ for 5 and $10 \% \mathrm{~m} \mathrm{v}^{-1}$, respectively (synthesis 2), noting that the reaction in synthesis 2 using CRL-AMP $10 \% \mathrm{~m} \mathrm{v}^{-1}$ showed higher productivity $\left(4220 \mu \mathrm{mol} \mathrm{min}^{-1} \mathrm{mg}_{\text {protein }}{ }^{-1}\right)$ and, consequently, better efficiency. It was expected that this reaction would be slower, because the alcohol used (cetyl alcohol) presents a greater number of carbon atoms in its structure, which would make the contact of the enzyme with the substrate more difficult. However, the system presented better productivity, that is, the enzyme presented a greater affinity to the system in the presence of cetyl alcohol. This result probably indicates that in synthesis 2 the diffusive and barrier effect were smaller, in other words, there was an accelerated mass transfer between the substrate and the enzyme, thus, the orientation of the enzymatic active site directed to the reaction medium improved the contact of the molecules of the substrate with the enzyme. The results obtained corroborate with Machado et al. (2019), in which the authors obtained faster reactions in the presence of cetyl alcohol.

\subsection{Reuse of CRL-AMP}

Immobilization has relevant industrial importance, since it improves the operational performance and, consequently, the cost-benefit ratio of enzymes in sustainable biocatalytic processes (Sheldon et al., 2013). Thus, the reuse of CRL-AMP at 5 and $10 \% \mathrm{~m} \mathrm{v}^{-1}$ was performed in the synthesis of esters 1 and 2. In synthesis 1, CRL-AMP $5 \% \mathrm{~m} \mathrm{v}^{-1}$ retained $37.5 \%$ of the catalytic activity after the fourth cycle, while with $10 \% \mathrm{~m} \mathrm{v}^{-1}$ concentration, it retained $46.5 \%$ after the fifth cycle and after the sixth cycle the activity decreased $20 \%$ (Fig. 4a). In synthesis 2 , it was observed that after the fifth reaction cycle with CRL-AMP $5 \% \mathrm{~m} \mathrm{v}^{-1}, 69.4 \%$ of the catalytic activity was still present, while with CRL-AMP $10 \%$, it retained $33.5 \%$ after the fifth reaction cycle (Fig. 4b). For all reuse calculations, 100\% of the reaction activity that preceded the cycles was considered. 

ability to reuse lipase after five reaction cycles. A progressive decrease of activity after consecutive cycles of reaction could be due to thermal inactivation of some CRL molecules and/or possible accumulation of water or alcohol molecules on the biocatalyst surface that lead to formation of a hydrophilic layer that restricts the partition of carboxylic acids to its microenvironment (Nasef et al., 2014; Lage et al., 2016). literature, it is observed that the immobilization procedure was efficient, since, Zare et al. (2018) immobilized Candia rugosa lipase on MIL-101 chromium terephthalate and obtained a residual activity of 20 to $30 \%$ after the first cycle of reuse, a value lower than that found in the present work in the fourth cycle, whose value obtained was $46.5 \%$ in synthesis 1 with $10 \% \mathrm{~m} \mathrm{v}^{-1}$ (Fig. 4a), and 69.4 and $33.5 \%$ in synthesis 2 with $5 \% \mathrm{~m} \mathrm{v}^{-1}$ (Fig. 4b).

Halin et al. (2019) reported the immobilization of CRL on a support of nylon microfibers and its application as a catalyst. An enzymatic load of $1000 \mathrm{mg} \mathrm{g}^{-1}$ was used, a content of immobilized enzyme that is approximately $10^{3}$ higher than the one used in the present study and approximately $50 \%$ residual activity was obtained after 4 cycles. The results obtained in the present study, with activity retention close to $50 \%$ after 5 cycles, suggests that AMP support can be used in the immobilization of CRL, since results similar to the consolidated data in the literature were obtained (Halin et al., 2019). Thus, the use of the AMP support in CRL immobilization is a promising alternative to preserve catalytic activity in esters synthesis using small amounts of protein, as well as enriching data from the literature in terms of enzymatic loading, specific activity, stability and recyclability.

307

\section{Conclusion}

309

The immobilization of Candida rugosa lipase on Accurel MP 1000 evaluated in this study showed high values of hydrolytic activity and specific esterified activity in organic medium, whose values demonstrate the efficiency of the immobilization process. The use of CRL-AMP in wax ester synthesis showed good conversions, since the reactions were performed in $60 \mathrm{~min}$ to 5 and $10 \%$ support and $6.5 \mathrm{mg}$ $\mathrm{g}^{-1}$ protein load. Through the CRL-AMP reusability tests, it was possible to verify that the immobilization 
Bandikari R, Qian J, Baskaran R, Liu Z, Wu G (2018) Bio-affinity mediated immobilization of lipase

made the CRL more stable and consequently, made reuse possible, since it showed activity retention after six cycles. Therefore, the application of this procedure at industrial levels becomes interesting.

Acknowledgements The Coordination for the Improvement of Higher Level Personnel (CAPES) for financial support and the State University of Santa Cruz (UESC) for administrative and technical support.

\section{Availability of data and material Not applicable}

Code availability Not applicable

\section{Compliance with ethical standards}

Conflict of interest The authors declare that they have no conflict of interest.

\section{References}

Alnoch RC, Martini VP, Glogauer A, Costa ACS, Piovan L, Muller-Santos M, de Souza EM, Pedrosa FO, Mitchell DA, Krieger N (2015) Immobilization and Characterization of a New Regioselective and Enantioselective Lipase Obtained from a Metagenomic Library. PLoS One 10:e0114945. https://doi.org/10.1371/journal.pone.0114945

Alves MD, Cren EC, Mendes AA (2016) Kinetic, thermodynamic, optimization and reusability studies for the enzymatic synthesis of a saturated wax ester. J Mol Catal 133:S377-S387. http://dx.doi.org/10.1016/j.molcatb.2017.02.011

Aransiola EF, Ojumu TV, Oyekola OO, Madzimbamuto TF, Ikhu-Omoregbe DIO (2014) A review of current technology for biodiesel production: State of the art. Biomass Bioenerg 61:276-297. https://doi.org/10.1016/j.biombioe.2013.11.014 onto magnetic cellulose nanospheres for high yield biodiesel in one time addition of methanol. Bioresour Technol 249:354-360. https://doi.org/10.1016/j.biortech.2017.09.156 
Baron AM, Zago EC, Mitchell DA, Krieger N (2011) SPIL: Simultaneous production and immobilization of lipase from Burkholderia cepacia LTEB11. Biocatal Biotransfor 29:19-24. https://doi.org/10.3109/10242422.2010.548556

Benamia F, Benouis S, Belafriekh A, Semache N, Rebbani N, Djeghaba Z (2016) Efficient Candida rugosa lipase immobilization on Maghnite clay and application for the production of (1R)-(2)-Menthyl acetate. Chem Pap 71:785-793. https://doi.org/10.1007/s11696-016-0080-9

352

Bento HBS, de Castro HF, de Oliveira PC, Freitas L (2017) Magnetized poly (STY-co-DVB) as a matrix for immobilizing microbial lipase to be used in biotransformation. J Magn Magn Mater 423:95-101. https://doi.org/10.1016/j.jmmm.2016.11.061

356

Bolina ICA, Salviano AB, Tardioli PW, Cren EC, Mendes AA (2018) Preparation of ion-exchange supports via activation of epoxy- $\mathrm{SiO}_{2}$ with glycine to immobilize microbial lipase - Use of biocatalysts in hydrolysis and esterification reactions. Int $\mathrm{J}$ Biol Macromol 120:2354-2365. https://doi.org/10.1016/j.ijbiomac.2018.08.190

361

Bradford MM (1976) A rapid and sensitive method for the quantitation of microgram quantities of protein utilizing the principle of protein-dye binding. Anal Biochem 72:248-254. https://doi.org/10.1016/00032697(76)90527-3

Carvalho T, Finotelli PV, Bonomo RCF, Franco M, Amaral PFF (2017) Evaluating Aqueous Two-Phase

Systems for Yarrowia lipolytica Extracellular Lipase Purification. Process Biochem 53:259-266. https://doi.org/10.1016/j.procbio.2016.11.019

Cavalcanti EDC, Aguieiras ECG, da Silva PR, Duarte JG, Cipolatti EP, Fernandez-Lafuente R, da Silva JAC, Freire DMG (2018) Improved production of biolubricants from soybean oil and different polyols via esterification reaction catalyzed by immobilized lipase from Candida rugosa. Fuel 215:705-713. https://doi.org/10.1016/j.fuel.2017.11.119 
Cea M, González ME, Abarzúa M, Navia R (2019) Enzymatic esterification of oleic acid by Candida rugosa lipase immobilized onto biochar. J Environ 242:171-177.

377 https://doi.org/10.1016/j.jenvman.2019.04.013

378

379 Cesarini S, Infanzón B, Pastor FIJ, Diaz P (2014) Fast and economic immobilization methods described for non-commercial Pseudomonas lipases. BMC Biotechnol 14:1-9. http://www.biomedcentral.com/1472-6750/14/27

382

Cui R, Ma S, Yang B, Li S, Pei T, Li J, Wang J, Sun S, Mi C (2020) Simultaneous removal of NOx and $\mathrm{SO}_{2}$ with $\mathrm{H}_{2} \mathrm{O}_{2}$ over silica sulfuric acid catalyst synthesized from fly ash. Waste Manage 109:65-74. https://doi.org/10.1016/ j.wasman.2020.04.049

386

Cunha AG, Besteti MD, Manoel EA, da Silva AAT, Almeira RV, Simas ABC, Fernandez-Lafuente R, Pinto JC, Freire DMG (2013) Preparation of Core-Shell Polymer Supports to immobilize lipase B from Candida antarctica. Effect of the support nature on catalytic properties. J Mol Catal B Enzym 100:59-67. http://dx.doi.org/10.1016/j.molcatb.2013.11.020

391

Da Silva APT, Bredda EH, de Castro HF, da Rós PCM (2020) Enzymatic catalysis: An environmentally friendly method to enhance the transesterification of microalgal oil with fusel oil for production of fatty acid esters with potential application as biolubricants. Fuel 273:117786. https://doi.org/10.1016/j.fuel.2020.117786

Da Silva MVC, Souza AB, de Castro HF, Aguiar LG, de Oliveira PC, de Freitas L (2020) Synthesis of 2ethylhexyl oleate catalyzed by Candida antarctica lipase immobilized on a magnetic polymer support in continuous flow. Bioproc Biosyst Eng 43:615-623. https://doi.org/10.1007/s00449-019-02257-9

400

401 De Menezes LHS, Carneiro LL, Tavares IMC, Santos PH, das Chagas TP, Mendes AA, da Silva EGP, Franco M, de Oliveira JR (2021) Artificial neural network hybridized with a genetic algorithm for optimization of lipase production from Penicillium roqueforti ATCC 10110 in solid-state fermentation. 
Dos Santos MMO, Gama RS, Tavares IMC, Santos PH, Gonçalves MS, de Carvalho MS, Boas EVBV, de Oliveira JR, Mendes AA, Franco M (2020) Application of lipase immobilized on a hydrophobic support for the synthesis of aromatic esters. Biotechnol Appl Biochem https://doi.org/10.1002/bab.1959

408

Esfandmaz S, Chaibakhsh N, Moradi-Shoeili Z, Mohammadi A (2018) Eco-friendly synthesis of maleate ester: A comparison between solid acid and enzyme-catalyzed esterification. Sustain Chem Pharm 8:8287. https://doi.org/10.1016/ j.scp.2018.03.003

412

Fernandes KV, Cavalcanti EDC, Cipolatti EP, Aguieiras ECG, Pinto MCC, Tavares FA, da Silva PR, Fernandez-Lafuente R, Arana-Peña S, Pinto JC, Assunção CLB, da Silva JAC, Freire DMG (2020) Enzymatic synthesis of biolubricants from by-product of soybean oil processing catalyzed by different

$$
\text { of }
$$

Candida

rugosa

lipase.

Catal Today

362:122-129. https://doi.org/10.1016/j.cattod.2020.03.060

418 cochenillifera. Chem Eng Commun 204:1167-1173. https://doi.org/10.1080/00986445.2017.1347567

422 https://doi.org/10.1016/j.enzmictec.2019.109439

426 https://doi.org/10.1016/j.biortech.2010.01.023

430 
Halin NIA, Al-Khatib MFR, Salleh HM, Nasef MM (2019) Immobilization of Candida rugosa Lipase on Aminated Polyvinyl Benzyl Chloride Grafted Nylon-6 Microfibers. Bull Chem React 14:369-379. https://doi.org/10.9767/bcrec.14.2.2894.369-379

Khan NR, Jadhav SV, Rathod VK (2015) Lipase catalysed synthesis of cetyl oleate using ultrasound: Optimisation and kinetic studies. Ultrason 27:522-529. https://doi.org/10.1016/j.ultsonch.2015.03.017

Kuo CH, Chen HH, Chen JH, Liu YC, Shieh CJ (2012) High yield of wax ester synthesized from cetyl alcohol and octanoic acid by Lipozyme RMIM and Novozym 435. Int J Mol Sci 13:11694-11704. https://doi.org/10.3390/ijms 130911694

Lage FAP, Bassi JS, Corradini MCC, Todero LM, Luiz JHH, Mendes AA (2016) Preparation of a biocatalyst via physical adsorption of lipase from Thermomyces lanuginosus on hydrophobic support to catalyze biolubricant synthesis by esterification reaction in a solvent-free system. Enzyme Microb Tech 84:56-67. https://doi.org/10.1016/j.enzmictec.2015.12.007

Lima LCD, Peres DGC, Mendes AA (2018) Kinetic and thermodynamic studies on the enzymatic synthesis of wax ester catalyzed by lipase immobilized on glutaraldehyde-activated rice husk particles. Bioprocess Biosyst Eng 41:991-100. https://doi.org/10.1007/s00449-018-1929-9

Machado NB, Miguez JP, Bolina ICA, Salviano AB, Gomes RAB, Tavano OL, Luiz JHH, Tardioli PW, Cren EC, Mendes AA (2019) Preparation, functionalization and characterization of rice husk silica for lipase immobilization via adsorption. Enzyme Microb Tech 128:9-21. https://doi.org/10.1016/j.enzmictec.2019.05.001

Madalozzo AD, Martini VP, Kuniyoshi KK, de Souza EM, Pedrosa FO, Glogauer A, Zanin GM, Mitchell DA, Krieger N (2015) Immobilization of LipC12, a new lipase obtained by metagenomics, and its application in the synthesis of biodiesel esters. J Mol Catal 116:45-51. http://dx.doi.org/10.1016/j.molcatb.2015.03.002 
DMG (2015) Accurel MP 1000 as a support for the immobilization of lipase from Burkholderia cepacia:

Application to the kinetic resolution of myo-inositol derivatives. Process Biochem 50:1557-1564. http://dx.doi.org/10.1016/j.procbio.2015.06.023

469

Manoel EA, Robert JM, Pinto MCC, Machado ACO, Besteti MD, Coelho MAZ, Simas ABC, Fernandez-

Lafuente R, Pinto JC, Freiro DMG (2016) Evaluation of the performance of differently immobilized recombinant lipase B from Candida antarctica preparations for the synthesis of pharmacological derivatives in organic media. RSC Adv 6:4043-4052. https://doi.org/10.1039/C5RA22508F

Miguez JP, Gama RS, Bolina ICA, de Melo CC, Cordeiro MR, Hirata DB, Mendes AA (2018) Enzymatic synthesis optimization of a cosmetic ester catalyzed by a homemade biocatalyst prepared via physical adsorption of lipase on amino functionalized rice husk silica. Chem Eng Res Des 139:296-308. https://doi.org/10.1016/j.cherd.2018.09.037

479

Nasef MM, Abbasi A, Ting TM (2014) New $\mathrm{CO}_{2}$ adsorbent containing aminated poly(glycidyl methacrylate) grafted onto irradiated PE-PP nonwoven sheet. Radiat Phys Chem 103:72-74. http://dx.doi.org/10.1016/j.radphyschem.2014.05.031

483

Novaes FJM, Junior II, Sutili FK, Marriott PJ, Bizzo HB, Neto FRA, de Souza, ROMA, Rezendo CM (2018) Lipase-catalysed esters synthesis of cafestol and kahweol. Food Chem 259:226-233. https://doi.org/10.1016/ j.foodchem.2018.03.111

487

Rani KNP, Neeharika TSVR, Kumar TP, Satyavathi B, Sailu C, Prasad RBN (2015) Kinetics of 489 enzymatic esterification of oleic acid and decanol for wax ester and evaluation of its physico-chemical properties. J Taiwan Inst Chem Eng. 55:12-16. https://doi.org/10.1016/j.jtice.2015.04.011

491

Sabbani S, Hedenstrom E, Nordin O (2006) The enantioselectivity of Candida rugosa lipase is influenced https://doi.org/10.1016/j.molcatb.2006.05.003 
505

506

507

508

509

510

511

521

522

Scherer R, Oliveira JV, Pergher S, de Oliveira D (2011) Screening of Supports for Immobilization of Commercial Porcine Pancreatic Lipase. Mat Res 14:483-492. https://doi.org/10.1590/S151614392011005000079

Serrano-Arnaldos M, Máximo-Martín MF, Montial-Morte MC, Ortega-Requena S, Gómez-Gómez E, Bastida-Rodríguez J (2016) Solvent-free enzymatic production of high quality cetyl esters. Bioprocess Biosyst Eng 39:641-649. https://doi.org/10.1007/s00449-016-1545-5

Sheldon RA, Van-Pelt S (2013) Enzyme immobilisation in biocatalysis: why, what and how. Chem Soc Rev 42:6223-6235. https://doi.org/10.1039/C3CS60075K

Silva MVC, de Souza CAP, de Oliveira PC, de Castro HF, Freitas L (2018) Isopropyl myristate continuous synthesis in a packed-bed reactor using lipase immobilized on magnetic polymer matrix. Int $\mathbf{J}$ Eng Res 4:12-20. http://doi.org/10.5281/zenodo. 1474108

Silva TP, Souza LO, Reis NS, Assis SA, Ferreira MLO, de Oliveira JR, Oliveira E A, Franco M (2017) Cultivation of Penicillium roqueforti in cocoa shell to produce and characterize its lipase extract. Rev Mex Ing Quim 16:745-756. http://rmiq.org/ojs311/index.php/rmiq/article/view/731

Teodoro LC, Hawkes JA, Mendes AA, Pereira EB (2019) Immobilization of Biotechnologically Important Candida rugosa Lipase onto Commercial Matrices. Int J Eng Res Gen Sci 5:1-6. http://doi.org/10.5281/zenodo.3370855

Ungcharoenwiwat P, H-Kittikun A (2015) Purification and characterization of lipase from Burkholderia sp. EQ3 isolated from wastewater from a canned fish factory and its application for the synthesis of wax esters. J Mol Catal B Enzym 115:96-104. https://doi.org/10.1016/j.molcatb.2015.02.005 
525 Zare A, Bordbar AK, Jafarian F, Tangestaninejad S (2018) Candida rugosa lipase immobilization on 526 various chemically modified Chromium terephthalate MIL-101. J Mol 254:137-144.

527 https://doi.org/10.1016/j.molliq.2018.01.097

528

$529 \quad$ Figure captions

530

531 Fig. 1 Scanning electron microscopy of the adsorbent resin Accurel MP 1000 (a) and (b) porosity with 20 532 and $100 \mu \mathrm{m}$ zoom, respectively

533

534 Fig. 2 Synthesis of dodecanoyl octadecanoate 1 and hexadecanoyl octadecanoate 2 catalyzed by CRL535 AMP

536

537 Fig. 3 Reactions catalyzed by CRL-AMP in the synthesis of (a) dodecanoyl octadecanoate 1 and (b) 538 hexadecanoyl octadecanoate 2 to 5 and $10 \% \mathrm{~m} \mathrm{v}^{-1}$ to $40{ }^{\circ} \mathrm{C}, 200 \mathrm{rpm}$ and $500 \mathrm{mmol} \mathrm{L}^{-1}$ of each reagent 539 (acid:alcohol) in heptane medium. The values are represented as mean \pm standard deviation of three 540 repetitions

541

542 Fig. 4 Studies of CRL-AMP reuse after 6 successive cycles of the synthesis of (a) dodecanoyl 543 octadecanoate 1 and (b) hexadecanoyl octadecanoate 2 to 5 and $10 \% \mathrm{~m} \mathrm{v}^{-1}$ in heptane medium

545 Table captions

546

547 Table 1 Conversion of esters synthesized by CRL-AMP $\left(5\right.$ and $\left.10 \% \mathrm{~m} \mathrm{v}^{-1}\right)$ at $40{ }^{\circ} \mathrm{C}$ and $200 \mathrm{rpm}$ 


\section{Figures}

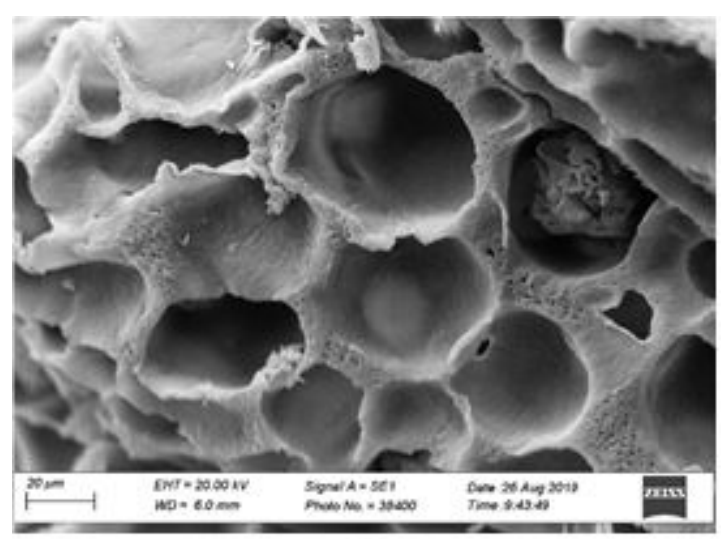

(a)

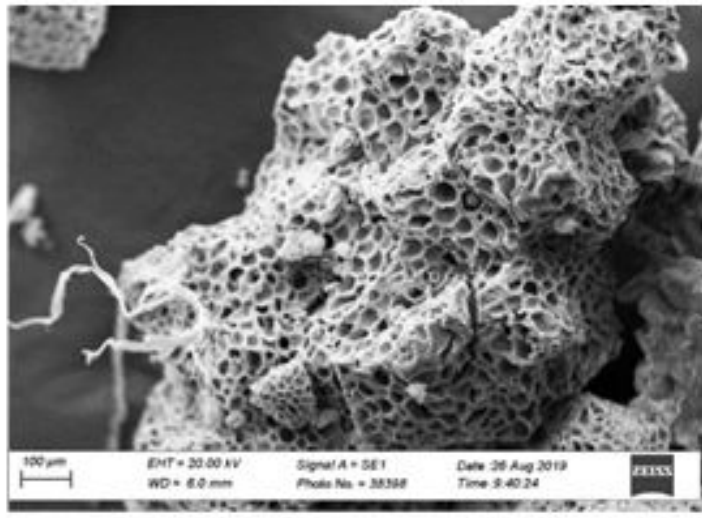

(b)

\section{Figure 1}

Scanning electron microscopy of the adsorbent resin Accurel MP 1000 (a) and (b) porosity with 20 and $100 \mu \mathrm{m}$ zoom, respectively

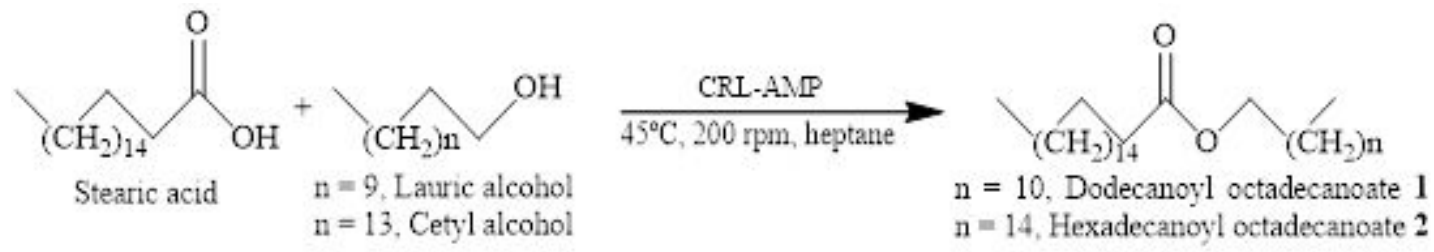

\section{Figure 2}

Synthesis of dodecanoyl octadecanoate 1 and hexadecanoyl octadecanoate 2 catalyzed by CRL-AMP 

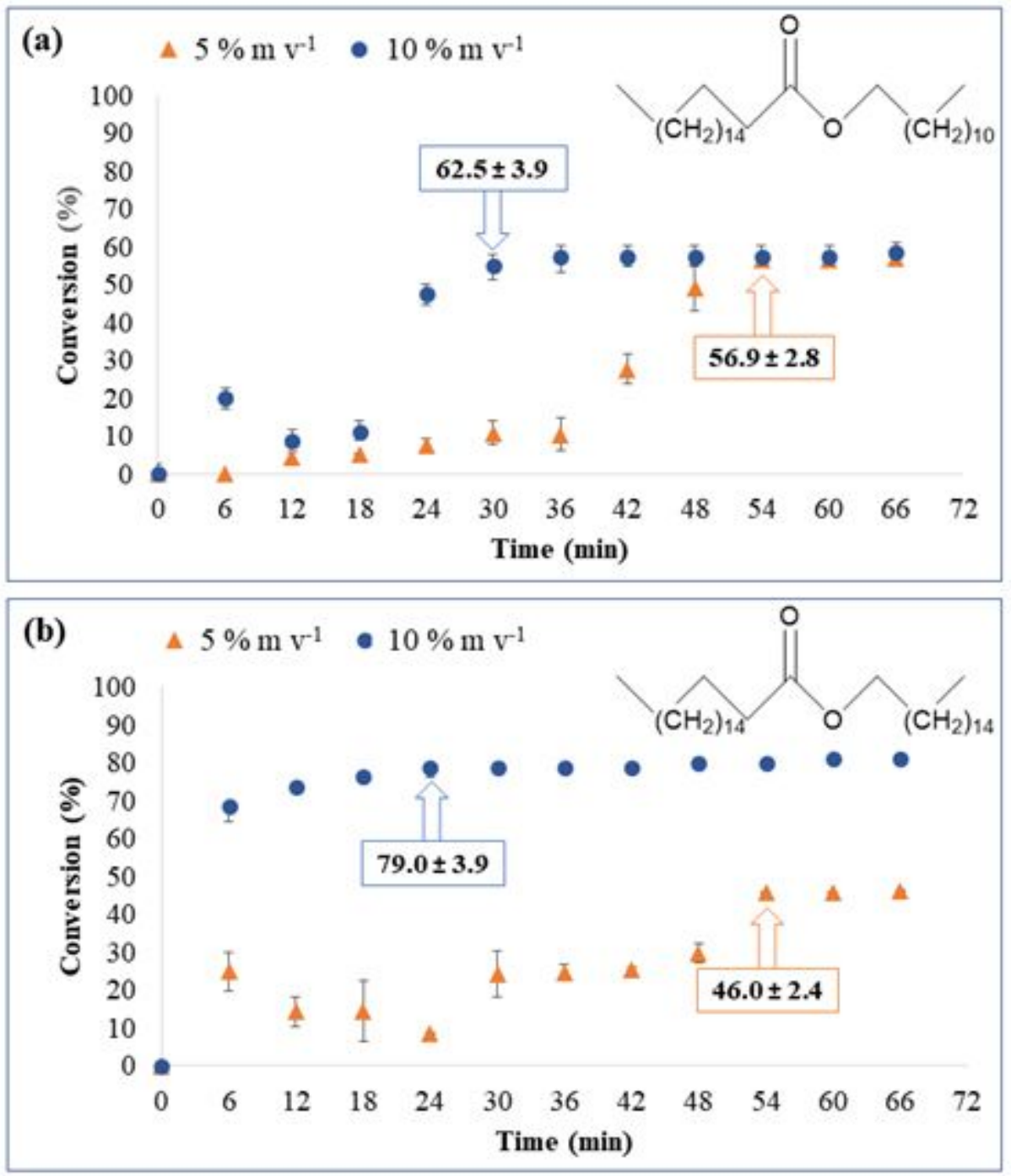

\section{Figure 3}

Reactions catalyzed by CRL-AMP in the synthesis of (a) dodecanoyl octadecanoate 1 and (b) hexadecanoyl octadecanoate 2 to 5 and $10 \% \mathrm{~m} \mathrm{v}-1$ to $40^{\circ} \mathrm{C}, 200 \mathrm{rpm}$ and $500 \mathrm{mmol} \mathrm{L}-1$ of each reagent (acid:alcohol) in heptane medium. The values are represented as mean \pm standard deviation of three repetitions 

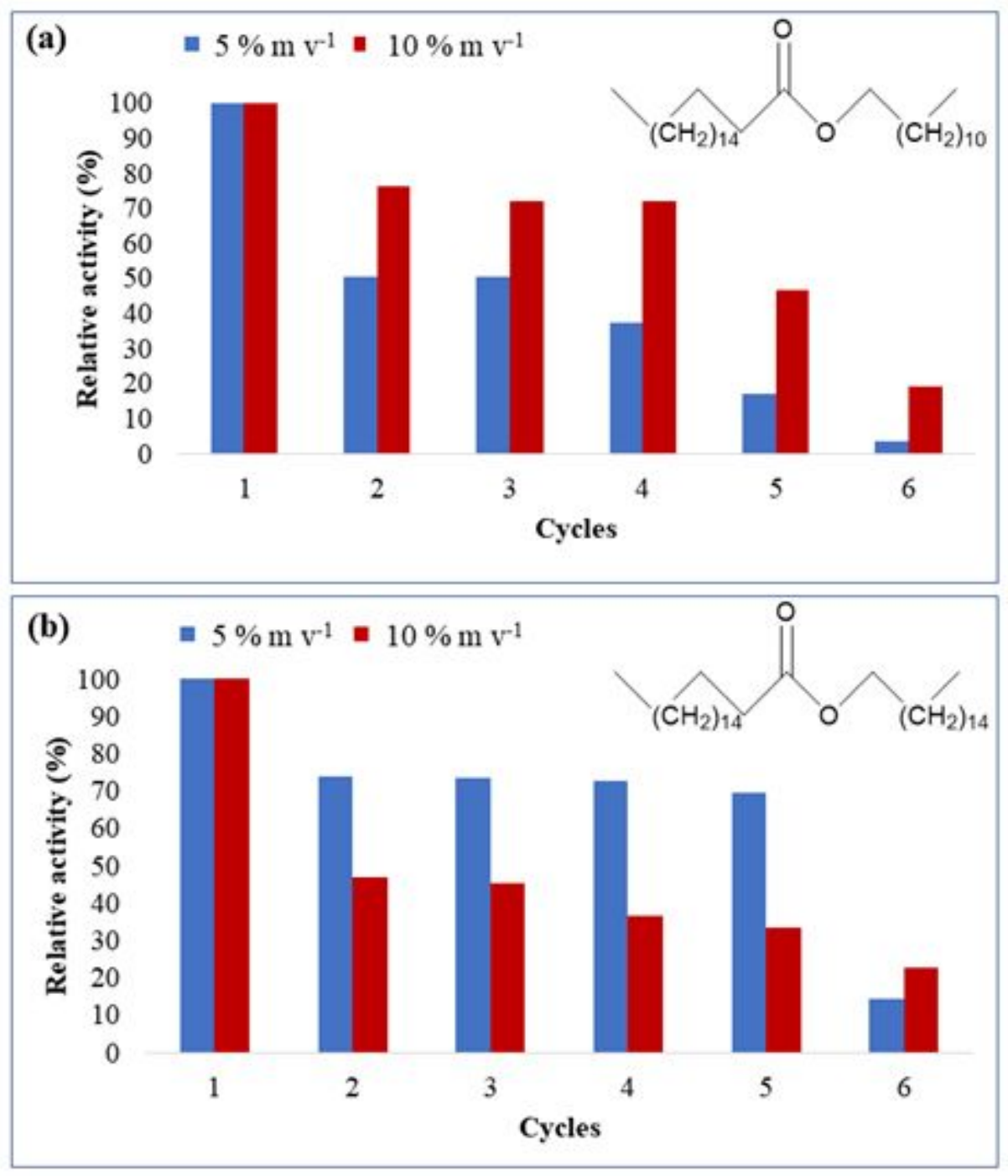

Figure 4

Studies of CRL-AMP reuse after 6 successive cycles of the synthesis of (a) dodecanoyl octadecanoate 1 and (b) hexadecanoyl octadecanoate 2 to 5 and $10 \% \mathrm{~m} \mathrm{v}-1$ in heptane medium 